\title{
6. GEOCHEMISTRY OF PORE WATER AND SEDIMENTS RECOVERED FROM LEG 136, HAWAIIAN ARCH ${ }^{1}$
}

\author{
Eric H. De Carlo ${ }^{2}$
}

\begin{abstract}
During Leg 136 drilling was conducted at two sites in pelagic sediments of the north central Pacific Ocean. In this report, pore-water analyses for major seawater constituents, alkalinity, ammonia, nitrate, phosphate, silica, $\mathrm{Ba}, \mathrm{Fe}, \mathrm{Li}, \mathrm{Mn}$, and $\mathrm{Sr}$ are presented. Although concentration gradients are generally weak, resulting from slow sedimentation and concomitant diffusive communication with overlying water, there is evidence of sediment/pore-water interactions, associated sediment diagenesis, and formation of authigenic minerals. Bulk major and trace element compositions of the sediments are consistent with reactions inferred to occur within the sediments and with the lithology and mineralogy. Elemental compositions of the sediments are not strongly affected by diagenesis and are primarily related to the dominant mineralogy. Sediments are typical of deep ocean pelagic settings with a significant contribution from the alteration of volcanic ash and the formation of zeolites. Sedimentary rare earth element patterns also provide evidence of active scavenging processes by $\mathrm{Mn}$ and $\mathrm{Fe}$ oxide phases in the deeper sediments at Site 842 .
\end{abstract}

\section{INTRODUCTION}

Drilling was conducted at two sites in deep ocean abyssal plain sediments of the north central Pacific Ocean during Leg 136 (Fig. 1). Pore water was sampled in Oligocene-early Miocene to Quaternary-age sediments (Firth and Hull, this volume; Hull, this volume) composed of silica-cemented claystones, pelagic red clays, and silty clays consisting of siliceous biogenic debris, volcanic ash, and authigenic minerals (Dziewonski, Wilkens, Firth, et al., 1992). Below approximately 35 meters below seafloor (mbsf), abundant silica-cemented claystones and cherts hampered core recovery and, hence, pore-water collection.

Shipboard pore-water analyses of salinity, $\mathrm{pH}$, alkalinity, ammonia, nitrate, phosphate, sulfate, silica, $\mathrm{Ca}, \mathrm{Cl}, \mathrm{Mg}, \mathrm{K}$, and $\mathrm{Sr}$, and shore-based determinations of $\mathrm{K}, \mathrm{Li}, \mathrm{Sr}, \mathrm{Ba}, \mathrm{Mn}$, and $\mathrm{Fe}$ concentrations in pore water are presented. The concentrations of major, minor, and trace elements including the rare earth elements (REE) in the corresponding sediment squeeze cakes are also provided. Pore-water profiles are briefly discussed in terms of sediment diagenesis and in relation to the lithology of the associated sediments. However, because recovery of pore-water samples was limited to a depth of less than $40 \mathrm{mbsf}$, interpretation of the data is limited.

\section{METHODS \\ Pore Water}

Whole-round $(5 \mathrm{~cm})$ core samples were handled in a Class 100 laminar flow hood because of an interest in determining trace elements in the interstitial water. Exposed portions of the whole-round cores (i.e., ends and material in contact with core liner) were removed with an acid-cleaned plastic spatula prior to shipboard squeezing at room temperature using a stainless steel press (Manheim and Sayles, 1974). Samples were collected in acid-cleaned $50-\mathrm{mL}$ syringes and then filtered through acid-cleaned $0.22-\mu \mathrm{m}$ Acrodisks. Splits for shore-based analyses were stored in acid-cleaned Nalgene bottles and acidified to $\mathrm{pH}<2$ with ultrapure $\mathrm{HNO}_{3}$. A split for shipboard alkalinity determination was filtered through unwashed Acrodisks. Two other splits, one of which was acidified, were stored in disposable plastic-capped test tubes and used for shipboard analyses. Alkalinity,

\footnotetext{
${ }^{1}$ Wilkens, R.H.,Firth, J., Bender, J., et al., 1993. Proc. ODP, Sci. Results, 136: College Station, TX (Ocean Drilling Program).

${ }^{2}$ Department of Oceanography, School of Ocean and Earth Science and Technology, 1000 Pope Rd., University of Hawaii, Honolulu, HI 96822, U.S.A.
}

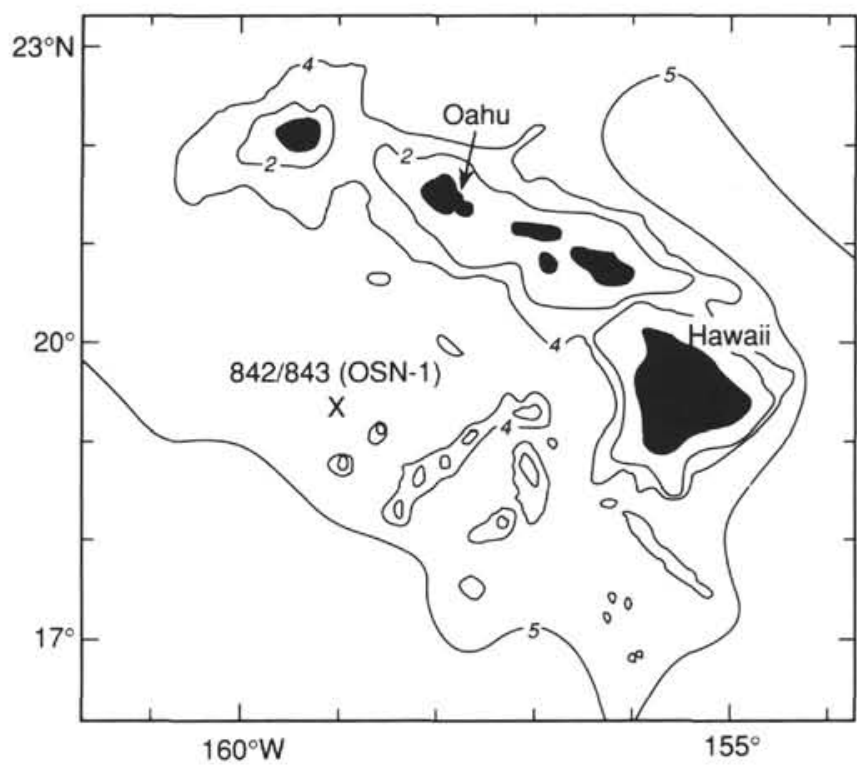

Figure 1. Area location map of Ocean Seismographic Network (OSN-1) area.

$\mathrm{pH}$, and salinity were determined immediately after sample collection. Methods employed at sea (titrimetric, spectrometric, ion chromatographic), including their relative precision and accuracy, have been described by Gieskes (1974), Gieskes and Peretsman (1986), and Gieskes et al. (1991), as well as in the "Explanatory Notes" chapter of the Initial Reports (Dziewonski, Wilkens, Firth, et al., 1992). Standards calibrated against or prepared from International Association for the Physical Sciences of the Ocean (IAPSO) seawater were used in all shipboard determinations. Acidified splits of samples were analyzed spectrometrically for the following constituents: $\mathrm{Li}, \mathrm{K}$, and $\mathrm{Sr}$ by flame atomic absorption-emission (AAS/AES); $\mathrm{Mn}$ and $\mathrm{Fe}$ by furnace atomic absorption (GFAAS); $\mathrm{Ba}, \mathrm{Ca}, \mathrm{Fe}, \mathrm{Mg}, \mathrm{Mn}$, and $\mathrm{Sr}$ by inductively coupled plasma optical emission (ICP/OES). Lanthanum chloride was used as a releasing agent in the shipboard determination of $\mathrm{Sr}$ by AAS. Commercial spectroscopic standards were used for calibration, IAPSO seawater and NIST traceable standard solutions were used as check standards in shore-based determinations. The relative precision and accuracy of ICP/OES analyses are approximately $2 \%-3 \%$ as determined by replicate analysis of samples, and 
IAPSO and NIST solutions, respectively. Sodium was determined by charge balance.

\section{Sediments}

The mineralogy of squeeze-cake sediments was determined at sea on untreated splits using the Philips 3520 automated X-ray diffractometer. Shore-based work was performed on portions of the wholeround squeeze cakes that were homogenized and dried at $110^{\circ} \mathrm{C}$ prior to further treatment. Mineralogy was determined ashore by X-ray diffraction (XRD) on a Scintag PAD-V automated diffractometer using $\mathrm{Cu}-\mathrm{K}_{\alpha}$ as a source of radiation and a solid-state detector. Shore-based results provided some evidence of minor phases not identified during shipboard analyses. The appearance of minor phase peaks on the diffractograms may simply result from slightly different orientation of the samples during analyses on the two instruments.

Major constituents of the sediments and selected trace elements were determined by X-ray fluorescence (XRF), whereas inductively coupled plasma/mass spectrometry (ICP/MS) was employed for a different suite of trace elements including the REE. Samples were prepared for XRF analysis by fusion of a 1:2 mixture of powdered sample and spec. pure lithium tetraborate $\left(\mathrm{Li}_{2} \mathrm{~B}_{4} \mathrm{O}_{7}\right)$. Fusion was effected for $5 \mathrm{~min}$ at $1000^{\circ} \mathrm{C}$, followed by cooling, regrinding of the disks, and a second fusion step to ensure the preparation of a homogeneous disk. The cooled disks were then polished, washed in an ultrasonic bath, dried, and loaded into the XRF spectrometer. Concentrations of the 27 constituents determined by XRF were measured by comparing the $\mathrm{X}$-ray intensity for each element with the intensity of two disks each of eight USGS standards (PCC-1, BCR-1, BIR-1, DNC-1, W-2, AGV-1, GSP-1, and G-2), using the values recommended by Flannagan (1976).

Instrumental performance and precision were evaluated using two fused disks of BCR-P and GSP-1 as internal standards. Precision is better than $1 \%$ for major constituents, but is highly variable for trace elements depending on their concentration. For example, the XRF precision for $\mathrm{Sc}$ is $7.7 \%$ at the $35 \mathrm{ppm}$ level, whereas it deteriorates to $61 \%$ at the $3.7 \mathrm{ppm}$ level. Elements whose estimated precision is poorer than $15 \%$ are not reported. The accuracy of XRF analyses was evaluated from the standard sample calibration curves by plotting calculated vs. observed intensities for each constituent. The absolute accuracy could not be quantified because no absolute standards were available.

Fusion beads of the sediments were also used in sample preparation for ICP/MS. The beads were digested in a mixture of concentrated mineral acid, evaporated to dryness, redissolved in $2 \mathrm{~mL} \mathrm{HClO}_{4}$ and once again taken to dryness. To the samples were added $3 \mathrm{~mL} \mathrm{HNO}_{3}$, 8 drops $\mathrm{H}_{2} \mathrm{O}_{2}$, and internals standards ( $\mathrm{Re}$ and $\mathrm{In}$ ). The samples were then diluted to $50 \mathrm{~mL}$ (1:250 final dilution). Raw intensities from the mass spectrometer were corrected for oxide and isobaric interferences (method modified after Lichte et al., 1987). Calibration curves for each element were constructed from intensities measured for acid blanks and three in-house rock standards that were previously calibrated against 11 international standards by plotting given values against the corrected intensities. Concentrations for the unknown samples were then computed from this curve. Precisions are better than $5 \%$ except for $\mathrm{Gd}(5 \%-10 \%)$, which suffers from slight $\mathrm{BaO}$ isobaric interferences. No absolute measure of the accuracy is available, but the accuracy can be estimated from the scatter of individual standards from a calibration line representing the best fit for all the standards. For trace elements determined by both XRF and ICP/MS (i.e., $\mathrm{Y}, \mathrm{Ba}, \mathrm{La}, \mathrm{Ce}, \mathrm{Pb}, \mathrm{Th}$ ), results from the latter are reported because of the greater accuracy of ICP/MS in trace analysis.

\section{RESULTS \\ Interstitial Water}

Profiles of the major pore-water constituents at Site 842 not presented in the Initial Reports volume (Dziewonski, Wilkens, Firth, et al., 1992) are shown in Figures 2 through 5. Data from Site 843 are not presented graphically, as only three pore-water samples were recovered. All pore-water data for Leg 136 sites are compiled in Table 1.

\section{Sediments}

Results of the bulk analyses of sediments by XRF and ICP/MS are presented in Tables 2 and 3, respectively. The composition of sediments is given primarily to assist in the evaluation of its influence on pore-water composition. Shale-normalized (Haskin et al., 1968) REE patterns of the sediments are shown in Figure 6. Mineralogical data are given in Tribble et al. (this volume).

\section{DISCUSSION}

The downhole increase in dissolved $\mathrm{Ca}$ and decrease in $\mathrm{Mg}$ at Site 842 (Table 1, Fig. 2) are similar to those commonly observed in slowly accumulating deep-sea sediments (Gieskes, 1981). A likely source of $\mathrm{Ca}$ is the alteration of volcanic glass and ash dispersed throughout the sediments (Kastner and Gieskes, 1976). An associated Mg depletion is largely attributable to the formation of authigenic minerals (smectite, zeolites) and the alteration of volcanic ash (Gieskes et al., 1987). The slope of the $\mathrm{Mg} / \mathrm{Ca}$ ratio (Fig. 2) changes below $18 \mathrm{mbsf}$ and coincides with the transition from Lithologic Unit I to Unit II. This suggests that the alteration reactions alluded to above may be less prevalent in the upper $20 \mathrm{~m}$ of sediments at Site 842 . Indeed, mineralogical evidence (Tribble et al., this volume) reveals a greater abundance of zeolites and smectites at depth within the sediments.

Dissolved $\mathrm{SiO}_{2}$ displays a more complex profile (Fig. 3). An initial decrease from approximately $300 \mu \mathrm{M}$ in the uppermost $10 \mathrm{mbsf}$ of Lithologic Unit 1 to less than $200 \mu \mathrm{M}$ between 10 and $20 \mathrm{mbsf}$ in Lithologic Unit I may be attributed to the early dissolution of radiolarians and a subsequent uptake of $\mathrm{SiO}_{2}$ during zeolite formation. Similar profiles are commonly observed features of deep-sea sediments (Gieskes, 1981, 1983; De Carlo, 1992). A subsequent downhole increase in dissolved $\mathrm{SiO}_{2}$ to greater than $600 \mu \mathrm{M}$ at 33 mbsf likely reflects an increased dissolution of opal-A within the sediments, although the occurrence of other reactions involving $\mathrm{SiO}_{2}$ cannot be excluded. The general covariance between dissolved $\mathrm{Li}$ and $\mathrm{SiO}_{2}(\mathrm{Fig}$. 3 ), however, is consistent with a release of $\mathrm{Li}$ during the dissolution of biogenic/amorphous silica. Because the conversion of opal-A to opal-CT becomes significant only in Core 136-842B-4H and below, dissolved $\mathrm{SiO}_{2}$ concentrations should also decrease only below this depth. The solid phase $\mathrm{SiO}_{2}$ concentration greater than $70 \%$ in Sample $136-842 \mathrm{~B}-4 \mathrm{H}-05,145-150 \mathrm{~cm}$ (Table 2) is consistent with the X-ray data indicating the presence of opal CT (Tribble et al., this volume), and this section of the sediments should be considered a transition zone where high dissolved and solid concentrations of $\mathrm{SiO}_{2}$ can coexist. Nonetheless, it should be borne in mind that $\mathrm{SiO}_{2}$ profiles in oceanic sediments are often complex, reflect the high reactivity of silica, and are strongly related to lithology (Gieskes, 1981).

Large increases in $\mathrm{Sr}$ pore-water concentrations are generally attributed to carbonate diagenesis (Baker et al., 1982); however, at Site 842 carbonate constitutes only approximately $10 \%$ of the sediments between 12 and $18 \mathrm{mbsf}$ and is completely absent below $24 \mathrm{mbsf}$ (Tribble et al., this volume). Furthermore, the $\mathrm{Sr} / \mathrm{Ca}$ ratio $\left(9 \times 10^{-3}\right)$ throughout Hole $842 \mathrm{~B}$ is nearly five times greater than the $\mathrm{Sr} / \mathrm{Ca}$ ratio in nannofossil oozes (approximately $2 \times 10^{-3}$ ) (Baker et al., 1982). Gieskes (1981) has reported an alternative source, from reactions of volcanic material in the sediments and/or from underlying basalt, that leads to small but distinct increases in dissolved $\mathrm{Sr}$, similar to those reported here. This may be a more important source of $\mathrm{Sr}$ to the pore water at Site 842 than the recrystallization of carbonates, considering the abundance of dispersed volcanic ash within sediments of Lithologic Units I and II. The generally low dissolved $\mathrm{Sr}$ concentrations, which increase significantly below only 20-25 mbsf, suggest either a limited extent of reactions within Lith- 
Table 1. Composition of pore water from Leg 136.

\begin{tabular}{|c|c|c|c|c|c|c|c|c|c|c|c|c|c|c|c|c|c|c|c|c|c|}
\hline $\begin{array}{l}\text { Sample } \\
(\mathrm{cm})\end{array}$ & $\begin{array}{c}\text { Volume } \\
\text { (mL) }\end{array}$ & $\begin{array}{l}\text { Depth } \\
\text { (mbsf) }\end{array}$ & $\mathrm{pH}$ & $\begin{array}{c}\text { Alkalinity } \\
\text { (mM) }\end{array}$ & $\begin{array}{c}\text { Salinity } \\
(\mathrm{g} / \mathrm{kg})\end{array}$ & $\underset{(\mathrm{mM})}{\mathrm{Cl}}$ & $\underset{(\mathrm{mM})}{\mathrm{Mg}}$ & $\begin{array}{c}\mathrm{Ca} \\
(\mathrm{mM})\end{array}$ & $\begin{array}{c}\text { Sr } \\
(\mu \mathrm{M})\end{array}$ & $\begin{array}{c}\mathrm{Ba} \\
(\mathrm{nM})\end{array}$ & $\mathrm{Mg} / \mathrm{Ca}$ & $\begin{array}{l}\mathrm{SO}_{4}^{2+} \\
(\mathrm{mM})\end{array}$ & $\begin{array}{l}\mathrm{PO}_{4}^{3+} \\
(\mu \mathrm{M})\end{array}$ & $\begin{array}{l}\mathrm{NH}_{4}^{+} \\
(\mu \mathrm{M})\end{array}$ & $\begin{array}{l}\mathrm{NO}_{3}^{-} \\
(\mu \mathrm{M})\end{array}$ & $\begin{array}{l}\mathrm{SiO}_{2} \\
(\mu \mathrm{M})\end{array}$ & $\underset{(\mathrm{mM})}{\mathrm{K}}$ & $\underset{(\mathrm{mM})}{\mathrm{Na}}$ & $\underset{(\mu \mathrm{M})}{\mathrm{Li}}$ & $\begin{array}{c}\mathrm{Mn} \\
(\mu \mathrm{M})\end{array}$ & $\begin{array}{c}\mathrm{Fc} \\
(\mu \mathrm{M})\end{array}$ \\
\hline \multicolumn{22}{|l|}{ Hole $842 \mathrm{~A}-$} \\
\hline $1 \mathrm{H}-2,145-150$ & 55 & 2.95 & 7.70 & 2.290 & 35.0 & 551 & 54.2 & 10.6 & 95.7 & 546 & 5.11 & 27.4 & 2.16 & 13.5 & 48.5 & 319 & 11 & 467 & 32.9 & 0.87 & 0.68 \\
\hline iH-5, 145-150 & 55 & 7.45 & 7.71 & 2.360 & 35.0 & 557 & 53.1 & 10.5 & 95.4 & 234 & 5.06 & 28.0 & 1.95 & 7.6 & 21.7 & 306 & 11 & 476 & 31.3 & 0.32 & 0.11 \\
\hline \multicolumn{22}{|l|}{ Hole 842B- } \\
\hline $1 \mathrm{H}-1,145-150$ & 45 & 1.45 & 7.80 & 2.490 & 34.8 & 554 & 53.0 & 10.3 & 96.9 & 234 & 5.17 & 27.7 & 2.57 & 16.4 & 20.7 & 323 & 11 & 474 & 31.0 & 0.11 & 0.65 \\
\hline IH $-3,145-150$ & 65 & 4.45 & 7.44 & 2.320 & 35.0 & 558 & 52.7 & 10.5 & 97.3 & 290 & 5.02 & 28.4 & 1.74 & 18.5 & 27.7 & 348 & ii & 479 & 30.9 & 0.16 & 0.24 \\
\hline $2 \mathrm{H}-3,145-150$ & 50 & 10.75 & & & 34.8 & 563 & 51.4 & 10.6 & 91.6 & 95 & 4.87 & 27.9 & 0.92 & 21.5 & 51.9 & 175 & ii & 483 & 27.8 & 0.71 & 0.60 \\
\hline $2 \mathrm{H}-5,145-150$ & 45 & 13.75 & 7.65 & 1.806 & 34.0 & 554 & 49.8 & 10.4 & 96.2 & & 4.80 & 28.5 & 0.95 & 19.3 & 28.5 & 193 & 12 & 480 & & 2.95 & 0.50 \\
\hline $3 \mathrm{H}-2,145-150$ & 40 & 18.75 & 7.41 & & 34.0 & 557 & 48.9 & 11.1 & 96.0 & 169 & 4.40 & 27.2 & 0.50 & 42.7 & 29.7 & 160 & 11 & 479 & 30.3 & 5.06 & 0.82 \\
\hline $3 \mathrm{H}-5,145-150$ & 30 & 23.25 & 7.57 & 1.530 & 34.0 & 548 & 50.7 & 12.0 & 99.7 & 617 & 4.23 & 26.8 & 0.71 & 23.7 & 24.3 & 263 & 12 & 466 & 32.1 & 5.24 & 0.75 \\
\hline $4 \mathrm{H}-2,145-150$ & 35 & 28.25 & 7.56 & 1.373 & 33.8 & 562 & 51.3 & 12.5 & 114 & 128 & 4.12 & 26.5 & 0.92 & 77.8 & 21.8 & 433 & 11 & 477 & 36.2 & 2.24 & 0.34 \\
\hline $4 \mathrm{H}-5,145-150$ & 35 & 32.75 & 7.57 & 1.323 & 34.5 & 564 & 50.5 & 12.8 & 103 & 128 & 3.95 & 27.8 & 1.12 & $150^{\circ}$ & 22.2 & 649 & 12 & 482 & 50.2 & 0.06 & 0.16 \\
\hline \multicolumn{22}{|l|}{ Hole $843 \mathrm{C}-$} \\
\hline $1 \mathrm{H}-1,145-150$ & 65 & 1.45 & 7.62 & 2.376 & 35.0 & 557 & 53.0 & 10.5 & 91.1 & & 5.07 & 28.9 & 2.41 & $<25$ & & 302 & 11 & 478 & 29.6 & 0.60 & 0.03 \\
\hline $1 \mathrm{H}-2,145-150$ & 55 & 2.95 & 7.63 & 2.266 & 35.0 & 554 & 52.6 & 10.8 & 94.5 & & 4.88 & 28.9 & 1.71 & $<25$ & & 327 & 11 & 476 & 28.5 & 4.03 & 0.06 \\
\hline 1H- $3,89-94$ & 70 & 3.89 & 7.69 & 2.215 & 35.5 & 555 & 52.8 & 10.8 & 95.1 & & 4.90 & 28.9 & 1.51 & $<25$ & & 335 & ii & 476 & 29.3 & 1.63 & 0.14 \\
\hline
\end{tabular}

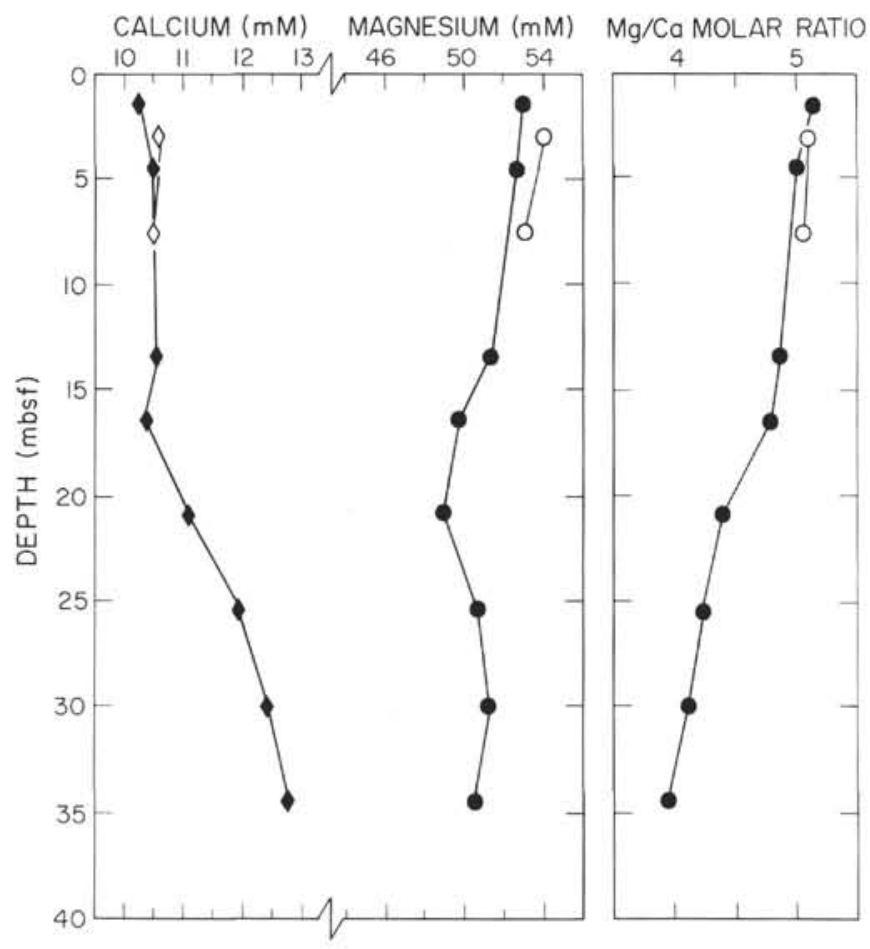

Figure 2. $\mathrm{Ca}$ and $\mathrm{Mg}$ pore-water profiles at Site 842 . Open symbols $=$ Hole $842 \mathrm{~A}$; closed symbols $=$ Hole $842 \mathrm{~B}$.

ologic Units I and II or an erasure of the Sr gradient through diffusive communication with overlying water.

Alkalinity, sulfate, and ammonia profiles are not discussed here, and the reader is referred to the Initial Reports volume (Dziewonski, Wilkens, Firth, et al., 1992).

Dissolved $\mathrm{PO}_{4}^{3-}$ concentrations are low throughout the sediments at Site 842 (Fig. 4). However, an initial negative gradient down to approximately $20 \mathrm{mbsf}$ is reversed in the last three interstitial water (IW) samples. Examination of the solid phase compositions presented in Table 2 reveals a corresponding five- to ten-fold enrichment of $\mathrm{P}_{2} \mathrm{O}_{5}$ in the deeper sediments and a similar increase in solid phase $\mathrm{Mn}$. The phosphatic component of the red clay sediments of Lithologic Unit II could be associated with $\mathrm{Fe}-\mathrm{Mn}$ oxides. Iron oxide surfaces scavenge $\mathrm{PO}_{4}^{3-}$ very efficiently (Feely et al., 1991), hence, any reductive dissolution of the Fe-Mn component of the sediments will contribute $\mathrm{PO}_{4}^{3-}$ to the pore water in addition to releasing $\mathrm{Fe}$ and $\mathrm{Mn}$.

The Mn and Fe profiles at Site 842 (Fig. 5) are likely associated with suboxic conditions within the sediments. Dissolved Mn concentrations, however, remain below $6 \mu \mathrm{M}$. The less-than-1- $\mu \mathrm{M}$ dissolved Mn concentrations observed in the upper 10 mbsf of Lithologic Unit I

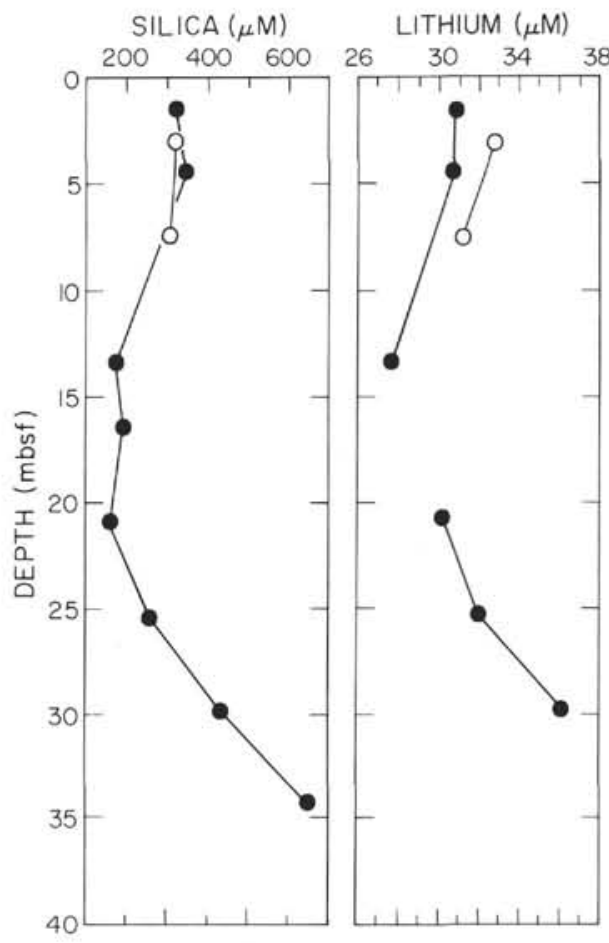

Figure 3. Si and Li pore-water profiles at Site 842. Open symbols = Hole 842A; closed symbols $=$ Hole 842B .

increase more than five-fold a few meters ( $18.75 \mathrm{mbsf}$ ) above the red clays of Lithologic Unit II. This increase occurs just above the level where solid phase Mn oxides (Table 2) increase to approximately $2 \%$ by weight (Sample 136-842B-3H-5, 145-150 cm) and suggests an upward diffusive flux of dissolved $\mathrm{Mn}$ from reactions in this zone. A return to near-2- $\mu \mathrm{M}$ dissolved $\mathrm{Mn}$ in Sample 136-842B-4H-2, 145$150 \mathrm{~cm}$, coincides with the highest sediment $\mathrm{Mn}$ (oxide) concentration; below this depth, the Mn concentration decreases further to less than $0.1 \mu \mathrm{M}$ levels.

The dissolved Fe profile essentially parallels that for $\mathrm{Mn}$ but with significantly lower concentrations $(<1 \mu \mathrm{M})$. Relatively elevated dissolved $\mathrm{Fe}$ concentrations in the two uppermost samples from Holes $842 \mathrm{~A}$ and $842 \mathrm{~B}$ may result from contamination during the initial coring process, although a reaction zone just under the sediment-water interface cannot be totally discounted. Gieskes (1983) has noted that siliceous sediments, such as those occurring at Site 842 , can serve as a source of dissolved $\mathrm{Mn}$, presumably because the presence of reactive organic carbon provides an effective reducing agent. However, it is more likely that dissolved $\mathrm{Fe}$ and Mn profiles observed at Site 842 are controlled by reactions of $\mathrm{Fe}$ and $\mathrm{Mn}$ oxides in the red clay sediments 
Table 2. Major element composition of Leg 136 sediments.

\begin{tabular}{|c|c|c|c|c|c|c|c|c|c|c|c|c|}
\hline $\begin{array}{c}\text { Sample } \\
(\mathrm{cm})\end{array}$ & $\begin{array}{l}\text { Depth } \\
\text { (mbsf) }\end{array}$ & $\begin{array}{l}\mathrm{SiO}_{2} \\
(\mathrm{wt} \%)\end{array}$ & $\begin{array}{l}\mathrm{Al}_{2} \mathrm{O}_{3} \\
\text { (wt } \% \text { ) }\end{array}$ & $\begin{array}{c}\mathrm{TiO}_{2} \\
(\mathrm{wt} \%)\end{array}$ & $\begin{array}{c}\mathrm{FeO} \\
(\mathrm{wt} \%)\end{array}$ & $\begin{array}{l}\mathrm{MnO} \\
\text { (wt\%) }\end{array}$ & $\begin{array}{c}\mathrm{CaO} \\
\text { (wt } \%)\end{array}$ & $\begin{array}{c}\mathrm{MgO} \\
(\mathrm{wt} \%)\end{array}$ & $\begin{array}{c}\mathrm{K}_{2} \mathrm{O} \\
\text { (wt \%) }\end{array}$ & $\begin{array}{l}\mathrm{Na}_{2} \mathrm{O} \\
(\mathrm{wt} \%)\end{array}$ & $\begin{array}{l}\mathrm{P}_{2} \mathrm{O}_{5} \\
\text { (wt \%) }\end{array}$ & Total \\
\hline \multicolumn{13}{|l|}{ Hole 842A- } \\
\hline $1 \mathrm{H}-2,145-150$ & 2.95 & 52.5 & 12.6 & 2.13 & 11.0 & 0.19 & 7.08 & 6.69 & 1.26 & 3.49 & 0.209 & 97.2 \\
\hline $1 \mathrm{H}-5,145-150$ & 7.45 & 52.6 & 13.1 & 2.24 & 11.1 & 0.26 & 4.93 & 5.31 & 1.91 & 3.74 & 0.213 & 95.3 \\
\hline \multicolumn{13}{|l|}{ Hole 842B- } \\
\hline $1 \mathrm{H}-1,145-150$ & 1.45 & 50.8 & 15.3 & 2.14 & 12.5 & 0.38 & 4.22 & 4.52 & 2.07 & 3.04 & 0.272 & 95.2 \\
\hline $1 \mathrm{H}-3,145-150$ & 4.45 & 51.7 & 14.2 & 2.01 & 11.0 & 0.31 & 4.86 & 5.29 & 1.92 & 3.72 & 0.245 & 95.3 \\
\hline $2 \mathrm{H}-3,145-150$ & 10.75 & 50.2 & 13.9 & 2.15 & 10.9 & 0.27 & 6.04 & 6.92 & 1.88 & 3.88 & 0.172 & 96.4 \\
\hline $2 \mathrm{H}-5,145-150$ & 13.75 & 49.6 & 13.6 & 2.21 & 11.6 & 0.12 & 3.11 & 6.25 & 3.05 & 4.54 & 0.132 & 94.2 \\
\hline $3 \mathrm{H}-2,145-150$ & 18.75 & 49.3 & 12.3 & 2.17 & 11.8 & 0.15 & 7.21 & 8.50 & 1.43 & 3.15 & 0.173 & 96.2 \\
\hline $3 \mathrm{H}-5,145-150$ & 23.25 & 54.0 & 16.4 & 0.86 & 7.3 & 1.98 & 2.59 & 3.06 & 3.33 & 3.79 & 0.931 & 94.3 \\
\hline $4 \mathrm{H}-2,145-150$ & 28.25 & 54.3 & 15.0 & 0.56 & 6.3 & 2.56 & 3.32 & 2.96 & 3.48 & 3.90 & 1.391 & 93.8 \\
\hline $4 \mathrm{H}-5,145-150$ & 32.75 & 71.0 & 8.5 & 0.32 & 3.6 & 1.35 & 2.43 & 2.62 & 1.66 & 2.21 & 1.214 & 94.9 \\
\hline \multicolumn{13}{|l|}{ Hole $843 \mathrm{C}$ - } \\
\hline $1 \mathrm{H}-1,145-150$ & 1.45 & 52.4 & 15.4 & 1.92 & 10.9 & 0.37 & 4.26 & 4.26 & 2.15 & 3.18 & 0.254 & 95.2 \\
\hline $1 \mathrm{H}-2,145-150$ & 2.95 & 51.9 & 12.7 & 2.22 & 11.1 & 0.18 & 8.15 & 7.54 & 0.96 & 3.05 & 0.205 & 98.1 \\
\hline $1 \mathrm{H}-3,89-94$ & 3.89 & 54.0 & 13.8 & 1.86 & 10.6 & 0.29 & 4.55 & 5.15 & 2.12 & 3.12 & 0.206 & 95.6 \\
\hline
\end{tabular}

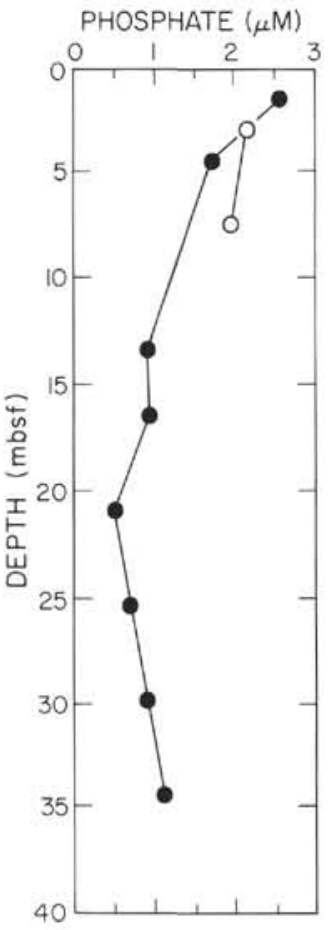

Figure 4. $\mathrm{P}$ pore-water profile at Site 842 . Open symbols $=$ Hole $842 \mathrm{~A}$; closed symbols $=$ Hole $842 \mathrm{~B}$.

of Lithologic Unit II. Total solid-phase Fe concentrations are lower in the region of the dissolved $\mathrm{Fe}$ and $\mathrm{Mn}$ maxima than at shallower depth (Table 2), but this results from most of the Fe present in sediments of Lithologic Unit I residing in volcanic matter, whereas in Unit II both the $\mathrm{Fe}$ and $\mathrm{Mn}$ occur predominantly as more reactive oxide minerals.

The REE distributions throughout the sediments of Site 842 provide evidence in support of the presence of reactive Fe-Mn oxides (Table 3). REE patterns of sediment samples exhibiting high solid phase Mn concentrations, rather than elevated Fe concentrations, reveal a clear Fe-Mn oxide mineral signature (Fig. 6), albeit with a pronounced negative $\mathrm{Ce}$ anomaly that has generally been associated with hydrothermal activity (e.g., Fleet, 1984; De Carlo et al., 1987; De Carlo and McMurtry, 1992) although the redox chemistry of Ce (e.g., Elderfield, 1988) allows it to remain in solution relative to its strictly trivalent neighbors $\mathrm{La}$ and $\mathrm{Pr}$ during suboxic diagenesis of sediments (Elderfield and Greaves, 1981).

The evidence presented herein demonstrates that the REE patterns of the red clays of Lithologic Unit II are controlled primarily by the

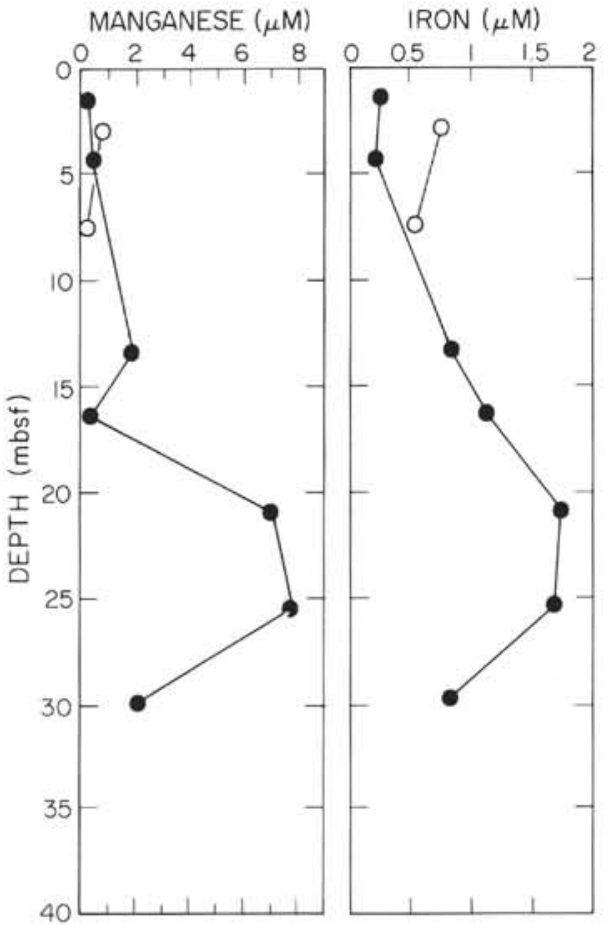

Figure 5. $\mathrm{Mn}$ and Fe pore-water profiles at Site 842. Open symbols $=$ Hole $842 \mathrm{~A}$; closed symbols $=$ Hole $842 \mathrm{~B}$.

sorptive properties of Fe-Mn oxides and the strongly diagenetic behavior of Mn. The difference in REE enrichment between Sample 136-842B-4H-5, 145-150 cm, and Samples 136-842B-3H-5, 145$150 \mathrm{~cm}$, and $136-842 \mathrm{~B}-4 \mathrm{H}-2,145-150 \mathrm{~cm}$, all of which are highly enriched in REE when compared with the sediments from Lithologic Unit I (Fig. 6), can easily be explained in terms of total Fe and Mn oxide abundances. Experimental work conducted in our laboratory (e.g., Koeppenkastrop et al., 1991; Koeppenkastrop and De Carlo, 1992) has shown that differences in REE enrichment can be attributed to either simple scavenging under conditions that parallel differences in available sorption sites, or to significant differences in exposure time to seawater and/or pore water from which the REE are scavenged. The former appears more likely here because samples from Sections 136-842B-3H-5 and 136-842B-4H-2 contain nearly twice the $\mathrm{Fe}$ and $\mathrm{Mn}$ as that from Section 136-842B-4H-5, which is reflected in approximately two to three times the REE content (Table 3).

The discussion above, however, does not explain the observed negative $\mathrm{Ce}$ anomalies. The majority of $\mathrm{Fe}-\mathrm{Mn}$ oxides in the marine 


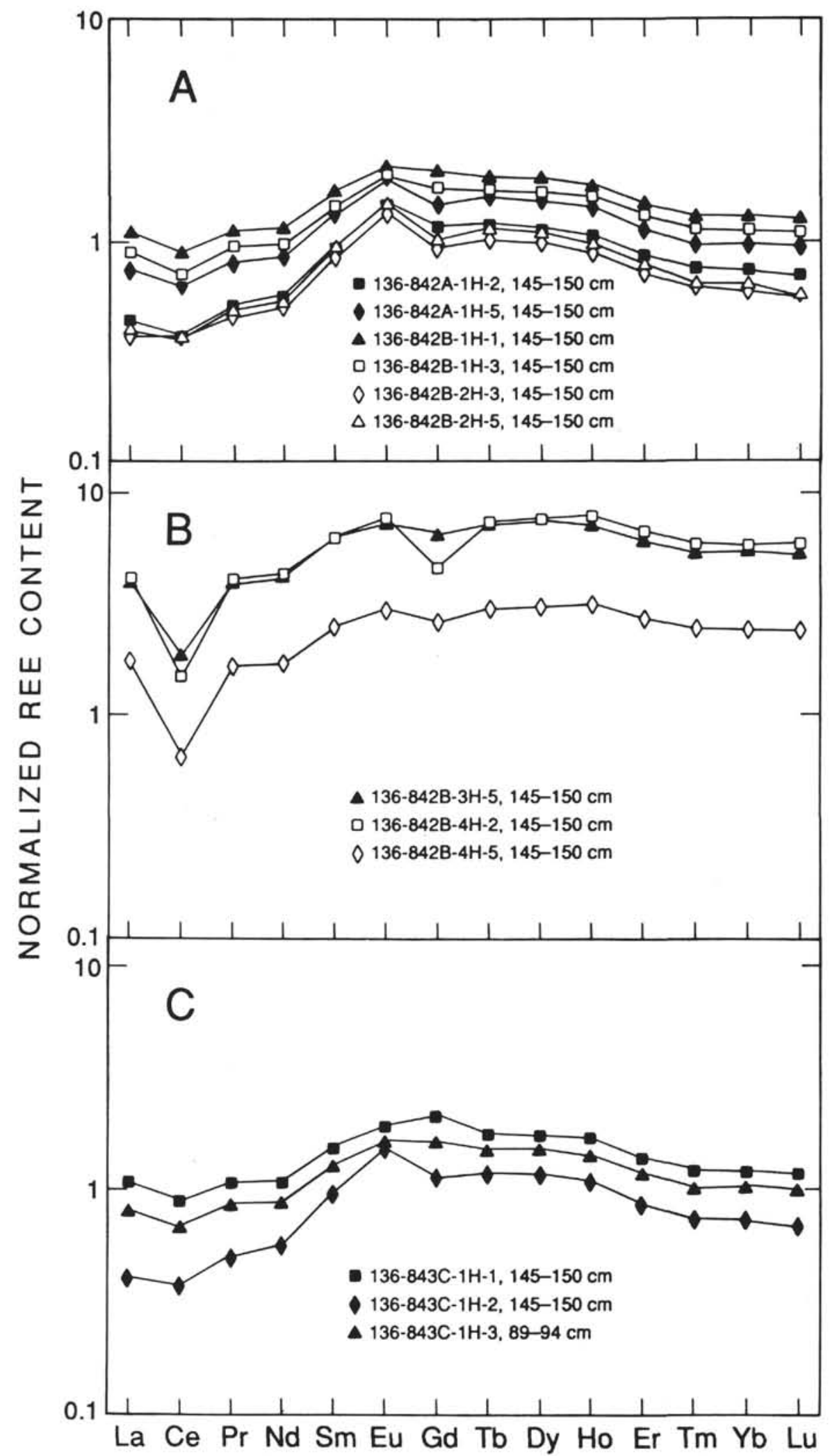

Figure 6. Shale-normalized REE patterns of Leg 136 sediments. A. Samples from Site 842, Lithologic Unit I. B. Samples from Site 842, Lithologic Unit II. C. Samples from Site 843. Note the weak extent of fractionation, near absence of a Ce anomaly, and near-shale concentrations of sediments from Site 842 , Lithologic Unit I, whereas patterns of sediments from Lithologic Unit II display greater light to heavy REE fractionation, significant $\mathrm{Ce}$ anomalies, and a greater overall REE enrichment relative to shales. 
Table 3. Trace and rare earth element composition of Leg 136 sediments.

\begin{tabular}{|c|c|c|c|c|c|c|c|c|c|c|c|c|c|c|c|c|c|c|}
\hline $\begin{array}{c}\text { Sample } \\
(\mathrm{cm})\end{array}$ & $\begin{array}{l}\text { Depth } \\
\text { (mbsf) }\end{array}$ & $\begin{array}{c}\mathrm{Ni} \\
(\mathrm{mg} / \mathrm{kg})\end{array}$ & $\begin{array}{c}\mathrm{Cr} \\
(\mathrm{mg} / \mathrm{kg})\end{array}$ & $\begin{array}{c}\mathrm{Sc} \\
(\mathrm{mg} / \mathrm{kg})\end{array}$ & $\begin{array}{c}\mathrm{V} \\
(\mathrm{mg} / \mathrm{kg})\end{array}$ & $\begin{array}{c}\mathrm{Sr} \\
(\mathrm{mg} / \mathrm{kg})\end{array}$ & $\begin{array}{c}\mathrm{Zr} \\
(\mathrm{mg} / \mathrm{kg})\end{array}$ & $\begin{array}{c}\mathrm{Ga} \\
(\mathrm{mg} / \mathrm{kg})\end{array}$ & $\underset{(\mathrm{mg} / \mathrm{kg})}{\mathrm{Ba}}$ & $\begin{array}{c}\mathrm{Rb} \\
(\mathrm{mg} / \mathrm{kg})\end{array}$ & $\begin{array}{c}\mathrm{Cs}_{(\mathrm{m}} \\
(\mathrm{mg} / \mathrm{kg})\end{array}$ & $\begin{array}{c}\mathrm{Nb} \\
(\mathrm{mg} / \mathrm{kg})\end{array}$ & $\begin{array}{c}\mathrm{Y} \\
(\mathrm{mg} / \mathrm{kg})\end{array}$ & $\begin{array}{c}\mathrm{Hf} \\
(\mathrm{mg} / \mathrm{kg})\end{array}$ & $\begin{array}{c}\mathrm{Ta} \\
(\mathrm{mg} / \mathrm{kg})\end{array}$ & $\underset{(\mathrm{mg} / \mathrm{kg})}{\mathrm{Cu}}$ & $\begin{array}{c}\mathrm{Zn} \\
(\mathrm{mg} / \mathrm{kg})\end{array}$ & $\begin{array}{c}\mathrm{Pb} \\
(\mathrm{mg} / \mathrm{kg})\end{array}$ \\
\hline \multicolumn{19}{|l|}{$842 \mathrm{~A}$ - } \\
\hline $1 \mathrm{H}-2,145-150$ & 2.95 & 120 & 352 & 32 & 227 & 269 & 128 & 17 & 680 & 21.2 & 1.03 & 10.2 & 29 & 2.98 & 0.74 & 155 & 107 & 5.98 \\
\hline $1 \mathrm{H}-5,145-150$ & 7.45 & 129 & 304 & 28 & 190 & 260 & 146 & 19 & 909 & 39.8 & 2.42 & 14.0 & 39 & 3.43 & 0.98 & 215 & 131 & 11.58 \\
\hline \multicolumn{19}{|l|}{$842 \mathrm{~B}-$} \\
\hline $1 \mathrm{H}-1,145-150$ & 1.45 & 114 & 252 & 26 & 223 & 302 & 175 & 21 & 2280 & 59.5 & 4.96 & 17.4 & 49 & 4.11 & 1.19 & 261 & 152 & 23.6 \\
\hline $1 \mathrm{H}-3,145-150$ & 4.45 & 149 & 338 & 26 & 192 & 279 & 153 & 19 & 1492 & 50.9 & 3.78 & 14.6 & 43 & 3.62 & 0.98 & 247 & 139 & 17.41 \\
\hline $2 \mathrm{H}-3,145-150$ & 10.75 & 224 & 551 & 33 & 200 & 238 & 132 & 19 & 378 & 26.7 & 0.79 & 10.5 & 24 & 3.04 & 0.71 & 181 & 114 & 4.21 \\
\hline $2 \mathrm{H}-5,145-150$ & 13.75 & 235 & 572 & 34 & 122 & 133 & 130 & 7 & 274 & 38.5 & 0.70 & 10.5 & 24 & 3.04 & 0.71 & 183 & 95 & 4.21 \\
\hline $3 \mathrm{H}-5,145-150$ & 23.25 & 397 & 57 & 38 & 119 & 294 & 218 & 19 & 399 & 84.1 & 7.17 & 16.4 & 226 & 5.63 & 0.94 & 495 & 152 & 42.35 \\
\hline $4 \mathrm{H}-2,145-150$ & 28.25 & 413 & 28 & 33 & 73 & 289 & 177 & 17 & 356 & 64.5 & 4.70 & 8.3 & 263 & 4.00 & 0.54 & 487 & 181 & 36.49 \\
\hline $4 \mathrm{H}-5,145-150$ & 32.75 & 205 & 28 & 13 & 43 & 161 & 93 & 10 & 187 & 33.9 & 2.76 & 3.6 & 11 & 1.77 & 0.24 & 171 & 161 & 18.74 \\
\hline \multicolumn{19}{|l|}{$843 \mathrm{C}-$} \\
\hline $1 \mathrm{H}-1,145-150$ & 1.45 & 108 & 241 & 19 & 189 & 298 & 166 & 23 & 2330 & 59.8 & 4.92 & 15.5 & 45 & 3.93 & 1.11 & 249 & 147 & 22.51 \\
\hline $1 \mathrm{H}-2,145-150$ & 2.95 & 141 & 387 & 25 & 254 & 269 & 128 & 21 & 448 & 16.0 & 0.78 & 10.3 & 28 & 3.11 & 0.73 & 136 & 105 & 3.75 \\
\hline $1 \mathrm{H}-3,79-84$ & 3.89 & 140 & 329 & 22 & 187 & 256 & 141 & 23 & 1531 & 54.1 & 3.84 & 12.5 & 38 & 3.37 & 0.92 & 212 & 126 & 17.2 \\
\hline
\end{tabular}

Table 3 (continued).

\begin{tabular}{cccccccccccccc}
\hline $\begin{array}{c}\text { Sample } \\
(\mathrm{cm})\end{array}$ & $\begin{array}{c}\text { Depth } \\
(\mathrm{mbs})\end{array}$ & $\begin{array}{c}\mathrm{La} \\
(\mathrm{mg} / \mathrm{kg})\end{array}$ & $\begin{array}{c}\mathrm{Ce} \\
(\mathrm{mg} / \mathrm{kg})\end{array}$ & $\begin{array}{c}\mathrm{Pr} \\
(\mathrm{mg} / \mathrm{kg})\end{array}$ & $\begin{array}{c}\mathrm{Nd} \\
(\mathrm{mg} / \mathrm{kg})\end{array}$ & $\begin{array}{c}\mathrm{Sm} \\
(\mathrm{mg} / \mathrm{kg})\end{array}$ & $\begin{array}{c}\mathrm{Eu} \\
(\mathrm{mg} / \mathrm{kg})\end{array}$ & $\begin{array}{c}\mathrm{Gd} \\
(\mathrm{mg} / \mathrm{kg})\end{array}$ & $\begin{array}{c}\mathrm{Tb} \\
(\mathrm{mg} / \mathrm{kg})\end{array}$ & $\begin{array}{c}\mathrm{Dy} \\
(\mathrm{mg} / \mathrm{kg})\end{array}$ & $\begin{array}{c}\mathrm{Ho} \\
(\mathrm{mg} / \mathrm{kg})\end{array}$ & $\begin{array}{c}\mathrm{Er} \\
(\mathrm{mg} / \mathrm{kg})\end{array}$ & $\begin{array}{c}\mathrm{Tm} \\
(\mathrm{mg} / \mathrm{kg})\end{array}$ \\
\hline \\
\hline
\end{tabular}

environment that are not of hydrothermal origin display REE patterns with positive or negligible Ce anomalies (Piper, 1974; Elderfield et al., 1981; Elderfield and Greaves, 1981; Aplin, 1984; De Carlo, 1991; De Carlo and McMurtry, 1992), although Palmer and Elderfield (1986) observed REE patterns of Fe-Mn oxide coatings of foraminifers to have strong negative $\mathrm{Ce}$ anomalies. The latter authors invoked the sensitivity of Fe-Mn oxide coatings on foraminifers to diagenesis to explain the shape of the REE patterns. Elderfield and Greaves (1981) also explained differences in Ce anomalies in deep-sea Fe-Mn nodules in terms of the $\mathrm{Mn} / \mathrm{Fe}$ ratio, with nodules exhibiting the greatest $\mathrm{Mn} / \mathrm{Fe}$ ratio having been subjected to the greatest diagenetic influence, hence, displaying more negative $\mathrm{Ce}$ anomalies. In Figure 7 the $\mathrm{Ce}$ anomaly, defined as $\mathrm{Ce} / \mathrm{Ce}^{*}=2\left(\mathrm{Ce} / \mathrm{Ce}_{\text {shale }}\right) /\left(\mathrm{La} / \mathrm{La}_{\text {shale }}+\right.$ $\mathrm{Pr} / \mathrm{Pr}_{\text {shale }}$ ), exhibits a negative relationship with the $\mathrm{Mn} / \mathrm{Fe}$ ratio of the bulk sediments. This observation suggests that the sediments at Site 842 have a diagenetic REE signature that is overwhelmingly influenced by Mn oxides.

The lithology of Site 842 comprises a mixture of authigenic and lithogenous (red clay and volcanic ash) material. Hence, the REE patterns of sediments in Lithologic Unit I, rather than resembling a seawater pattern (Ruhlin and Owen, 1986; Olivarez and Owen, 1989) or a hydrogenous Fe-Mn oxide pattern (Elderfield et al., 1981; De Carlo et al., 1987; De Carlo, 1991; De Carlo and McMurtry, 1992), reveal a contribution from volcanic ash as well as a shale- or crust-like pattern. The REE patterns of sediments recovered from shallower than 20 mbsf (Fig. 3) are typical of non-metalliferous sediments. They exhibit less fractionation between the light rare-earth elements (LREE) and heavy rare-earth elements (HREE), negligible Ce anomalies, and REE concentrations nearer those of shales. However, the influence of volcanic ash on the REE composition can be discerned in a plot of $\mathrm{La} / \mathrm{Yb}$ vs. $\mathrm{TiO}_{2} / \mathrm{Al}_{2} \mathrm{O}_{3}$ (Fig. 8). Sediments displaying $\mathrm{TiO}_{2} / \mathrm{Al}_{2} \mathrm{O}_{3}$ values between 0.13 and 0.18 fall in two fields, each of which exhibits a strong inverse relationship between $\mathrm{La} / \mathrm{Yb}$ and $\mathrm{TiO}_{2} / \mathrm{Al}_{2} \mathrm{O}_{3}$, whereas

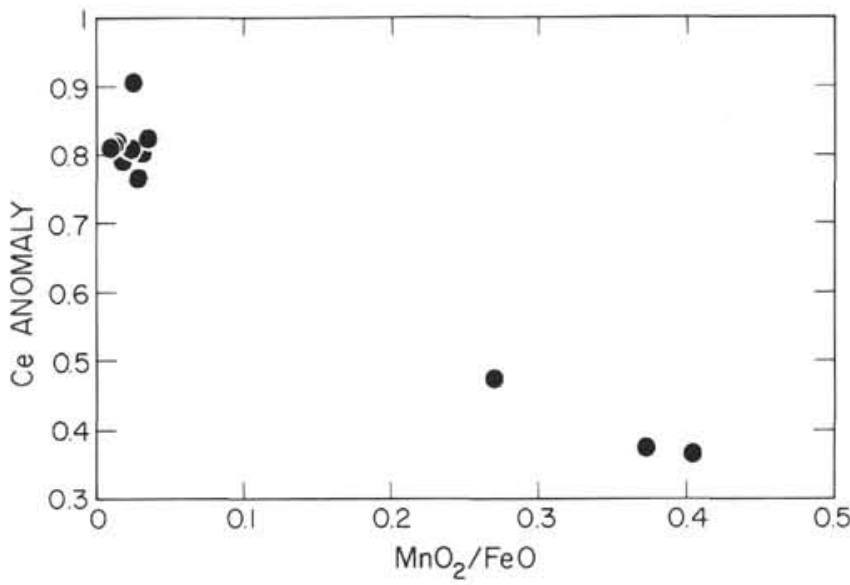

Figure 7. Ce anomaly vs. $\mathrm{MnO}_{2} / \mathrm{FeO}$ ratio of Leg 136 sediments. Values below 1.0 are considered negative anomalies. Note the more pronounced negative $\mathrm{Ce}$ anomalies with increasing $\mathrm{MnO}_{2} / \mathrm{FeO}$ ratio.

those enriched in Fe-Mn oxides fall in a distinct field with $\mathrm{TiO}_{2} / \mathrm{Al}_{2} \mathrm{O}_{3}$ ratios near 0.05 and a nearly constant $\mathrm{La} / \mathrm{Yb}$ ratio. Basalts from Hole $843 \mathrm{~B}$ exhibit a $\mathrm{TiO}_{2} / \mathrm{Al}_{2} \mathrm{O}_{3}$ ratio near 0.13 (Dziewonski, Wilkens, Firth, et al., 1992), whereas the $\mathrm{TiO}_{2} / \mathrm{Al}_{2} \mathrm{O}_{3}$ ratio in pure ashes ranges between 0.116 and 0.192 (Garcia, pers. comm., 1992).

\section{SUMMARY AND CONCLUSIONS}

Major constituent pore-water profiles at Site 842 result primarily from the alteration of volcanic matter and from the early diagenesis of silica. Except for complex dissolved $\mathrm{SiO}_{2}$ gradients, reflecting its 


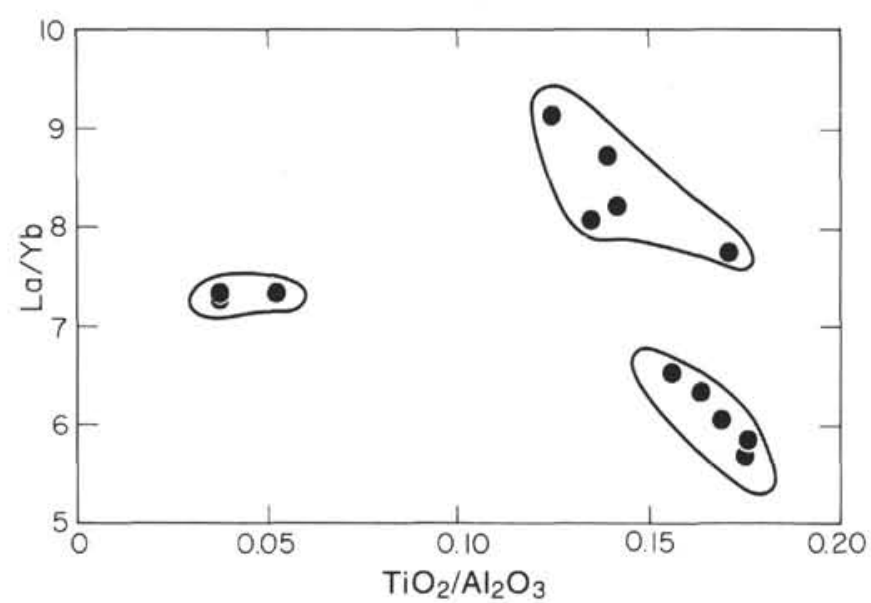

Figure 8. $\mathrm{La} / \mathrm{Yb}$ of Leg 136 sediments plotted vs. $\mathrm{TiO}_{2} / \mathrm{Al}_{2} \mathrm{O}_{3}$. Note the distinct fields corresponding to sediments enriched in volcanic matter (high $\mathrm{TiO}_{2} /$ $\mathrm{Al}_{2} \mathrm{O}_{3}$ ) and those enriched in reactive $\mathrm{Fe}-\mathrm{Mn}$ oxides (low $\mathrm{TiO}_{2} / \mathrm{Al}_{2} \mathrm{O}_{3}$ ).

high reactivity and the sedimentary lithology (Lerman, 1977; Gieskes, 1981), the diffusive communication with overlying seawater that results from slow sedimentation rates at Site 842 leads to a gradual erasure of pore-water concentration gradients. Dissolved profiles of $\mathrm{Fe}, \mathrm{Mn}$, and $\mathrm{PO}_{4}^{3-}$ appear to be controlled by reactions involving Fe-Mn oxides in the red clay sediments of Lithologic Unit II. The presence of reactive Fe-Mn oxides is supported by the REE profiles, which appear to have been acquired under conditions of suboxic diagenesis. The REE patterns are also consistent with the presence of basic ashes in the sediments of Lithologic Unit I.

\section{ACKNOWLEDGMENTS}

I wish to express my appreciation to shipboard colleagues for providing a collegial working environment. Kudos to Mary Cusimano and Chieh Peng, and to Charles Fraley and Xi-Yuan Wen, for technical assistance at sea and on shore, respectively. Discussions with J. Tribble and R. Wilkens and reviews and suggestions by J. Gieskes and R.W. Murray were particularly helpful in improving this manuscript. The financial research support provided by JOI/USSAC is deeply appreciated. This is SOEST contribution number 3244 .

\section{REFERENCES*}

Aplin, A.C., 1984. Rare earth element geochemistry of Central Pacific ferromanganese encrustations. Earth Planet. Sci. Lett., 71:13-22.

Baker, P.A., Gieskes, J.M., and Elderfield, H., 1982. Diagenesis of carbonates in deep-sea sediments: evidence from $\mathrm{Sr}^{2+} / \mathrm{Ca}^{2+}$ ratios and interstitial dissolved $\mathrm{Sr}^{2+}$ data. J. Sediment. Petrol., 52:71-82.

De Carlo, E.H., 1991. Paleoceanographic implications of intrasample rare earth element variability in a marine $\mathrm{Fe}-\mathrm{Mn}$ crust from the Hawaiian Archipelago. Mar: Geol., 98:449-467.

1992. Geochemistry of pore water and sediments recovered from the Exmouth Plateau. In von Rad, U., Haq, B.U., et al., Proc. ODP. Sci. Results, 122: College Station, TX (Ocean Drilling Program), 295-308.

De Carlo, E.H., and McMurtry, G.M., 1992. Rare earth element geochemistry of seamount ferromanganese deposits from the Hawaiian Archipelago. Chem. Geol., 95:235-250.

De Carlo, E.H., McMurtry, G.M., and Kim, K.H., 1987. Geochemistry of ferromanganese crusts from the Hawaiian archipelago. I. Northern survey areas. Deep-Sea Res. Part A, 34:441-467.

- Abbreviations for names of organizations and publications in ODP reference lists follow the style given in Chemical Abstracts Service Source Index (published by American Chemical Society).
Dziewonski, A., Wilkens, R., Firth, J., et al., 1992. Proc. ODP, Init. Repts., 136: College Station, TX (Ocean Drilling Program).

Elderfield, H., 1988. The oceanic chemistry of the rare-earth elements. Philos. Trans. R. Soc, London A, 325:105-126.

Elderfield, H., and Greaves, M.J., 1981. Negative cerium anomalies in the rare earth element patterns of oceanic ferromanganese nodules. Earth Planet. Sci. Lett., 55:163-170.

Elderfield, H., Hawkesworth, C.J., Greaves, M.J., and Calvert, S.E., 1981. Rare earth element geochemistry of oceanic ferromanganese nodules and associated sediments. Geochim. Cosmochim. Acta, 45:513-528.

Feely, R.A., Trefry, J.H., Massoth, G.J., and Metz, S., 1991. A comparison of the scavenging of phosphorus and arsenic from seawater by hydrothermal oxyhydroxides in the Atlantic and Pacific Oceans. Deep Sea Res. Part A, 38:617-623.

Fleet, A.J., 1984. Aqueous and sedimentary geochemistry of the rare earth elements. In Henderson, P. (Ed.), Rare Earth Element Geochemistry: New York (Elsevier), 343-373.

Gieskes, J.M., 1974. Interstitial water studies, Leg 25. In Simpson, E.S.W., Schlich, R., et al., Init. Repts. DSDP, 25: Washington (U.S. Govt. Printing Office), 361-394.

1981. Deep-sea drilling interstitial water studies: implications for chemical alteration of the oceanic crust, Layers I and II. In Warme, J.E., Douglas, R.G., and Winterer, E.L. (Eds.), The Deep Sea Drilling Project: A Decade of Progress. Spec. Publ.-Soc. Econ. Paleontol. Mineral., 32:149-167.

1983. The chemistry of interstitial waters of deep-sea sediments: interpretation of deep-sea drilling data. In Riley, J.P., and Chester, R. (Eds.), Chemical Oceanography (Vol. 8): London (Academic Press), 222-269.

Gieskes, J.M., Gamo, T., and Brumsack, H.J., 1991. Chemical methods for interstitial water analysis aboard JOIDES Resolution. ODP Tech. Note, 15 .

Gieskes, J.M., Lawrence, J.R., Perry, E.A., Grady, S.J., and Elderfield, H., 1987. Chemistry of interstitial waters and sediments in the Norwegian-Greenland Sea, Deep Sea Drilling Project Leg 38. Chem. Geol., 63:143-155.

Gieskes, J.M., and Peretsman, G., 1986. Procedures of interstitial water analysis. ODP Tech. Note, 5.

Haskin, L.A., Haskin, M.A., Frey, F.A., and Wildeman, T.R., 1968. Relative and absolute terrestrial abundances of the rare earths. In Ahrens, L.H.(Ed.), Origin and Distribution of the Elements: New York (Pergamon), 889-912.

Kastner, M., and Gieskes, J.M., 1976. Interstitial water profiles and sites of diagenetic reactions, Leg 35, DSDP, Bellingshausen Abyssal Plain. Earth Planet. Sci. Lett., 33:11-20.

Koeppenkastrop, D., and De Carlo, E.H., 1992. Sorption of rare earth elements from seawater onto pure mineral phases: an experimental approach. Chem. Geol., 95:251-263.

Koeppenkastrop, D., De Carlo, E.H., and Roth, M., 1991. A method to investigate the interaction of rare earth elements with metal oxides in aqueous solution. J. Radioanal. Nucl. Chem., 151:337-346.

Lerman, A., 1977. Migrational processes and chemical reactions in interstitial waters. In Goldberg, E.D., and McCave, I.N. (Eds.), The Sea (Vol. 6): New York (Wiley), 695-738.

Lichte, F.E., Meier, A.L., and Crock, J.G., 1987. Determination of rare earth elements in geological materials by inductively coupled mass spectrometry. Anal. Chem., 59:1150-1157.

Manheim, F.T., and Sayles, F.L., 1974. Composition and origin of interstitial waters of marine sediments based on deep sea drill cores. In Goldberg, E.D. (Ed.), The Sea (Vol. 5): New York (Wiley Interscience), 527-568.

Olivarez, A.M., and Owen, R.M., 1989. REE/Fe variations in hydrothermal sediments: implications for the REE content of seawater. Geochim. Cosmochim. Acta, 53:757-762.

Palmer, M.R., and Elderfield, H., 1986. Rare earth elements and neodymium isotopes in ferromanganese oxide coatings of Cenozoic foraminifera from the Atlantic Ocean. Geochim. Cosmochim. Acta, 50:409-417.

Piper, D.Z., 1974. Rare earth elements in ferromanganese nodules and other marine phases. Geochim. Cosmochim. Acta, 38:1007-1022.

Ruhlin, D.E., and Owen, R.M., 1986. The rare earth element geochemistry of hydrothermal sediments from the East Pacific Rise: examination of a seawater scavenging mechanism. Geochim. Cosmochim. Acta, 50:393-400.

Date of initial receipt: 23 October 1992

Date of acceptance: 26 April 1993

Ms 136SR-206 